\title{
PERANAN PUPUK ORGANIK CAIR TERHADAP KUALITAS HIJAUAN PAKAN TERNAK (HPT) ASAL TANAMAN PADI RATOON
}

\section{The Role of Liquid Organic Fertilizers on Forage Animal Feed Quality of Ratoon Rice Crops}

\author{
Jamilah $^{1 *}$, Sri Mulyani ${ }^{1}$ dan Yusnaweti ${ }^{2}$ \\ ${ }^{1}$ Program Studi Agroteknologi dan Peternakan Fakultas Pertanian Universitas Tamansiswa; \\ Padang, 25138. \\ ${ }^{2}$ Program studi Agroteknologi Fakultas Pertanian Universitas Muhammadiyah Sumatera Barat, \\ Padang, 25171 \\ email *) jamilahfatika@gmail.com
}

\begin{abstract}
ABSTRAK
Penelitian ini dilakukan di Nagari Ikur Lubuk Kecamatan Padang Panjang Timur, Kota Padang Panjang, dengan ketinggian tempat $720 \mathrm{~m}$ dari atas permukaan laut. Percobaan dilakukan pada bulan Maret 2017- Juli 2017, dengan tujuan mendapatkan jenis padi ratoon dan pupuk organik cair yang tepat untuk menghasilkan hijauan pakan ternak (HPT). Percobaan disusun dalam Rancangan Acak Kelompok dalam bentuk split plot, dengan petak utama adalah tanaman padi yaitu; Cisokan dan Pandan Wangi. Anak petak terdiri atas tiga jenis pupuk organik cair yaitu; Crocober Plus, Unitas Super dan POC Komersial NASA, sebanyak tiga kelompok sehingga menjadi 18 plot percobaan. Pemangkasan HPT dilakukan pada saat 30 hari setelah pangkas ratoon. Data yang diperoleh dianalisis dengan uji $\mathrm{F}$ pada taraf nyata 5\%, kalau perlakuan berpengaruh nyata dilanjutkan dengan uji Beda Nyata Terkecil (BNT) taraf nyata 5\%. Peubah yang diamati meliputi analisis proksimat, kecernaan dari protein kasar, lemak, serat kasar, bahan organik, bahan kering, acid detergent fibre (ADF), (NDF) hemi sellulosa, sellulosa, dan bahan ekstrak tanpa nitrogen (BETN). Dari hasil percobaan dapat disimpulkan bahwa padi Pandan Wangi mampu menghasilkan bobot segar HPT tertinggi dengan kualitas terbaik jika diberi 10\% POC Unitas Super.

Kata kunci: Cisokan, hijauan pakan ternak, padi ratoon, Pandan Wangi, pupuk organik cair
\end{abstract}

\begin{abstract}
The research had been done in Nagari Ikur Lubuk Padang Panjang East District, Padang Panjang City, with a height of 720 m above sea level. The experiments were conducted on March 2017-July 2017. The aimed of this research was to obtain the best variety of rice and liquid organic fertilizer to produce a good forage feed. The experiments were arranged in a split-plot, the main plot being the rice crop; Cisokan and Pandan Wangi. The subplot consists of three types of organic liquid fertilizer (OLF), namely; Crocober Plus, Unitas Super, and NASA Commercial LOF replicate 3 times to 18 plots. Forage pruning was done at 30 days after cutting ratoon. The data obtained were analyzed by $F$ test $5 \%$ real level, if the treatment had real effect followed by Significant Difference-(LSD) test 5\% real level. The included proximate analysis, digestibility of crude protein, fat, crude fiber, organic matter, dry matter, acid detergent fiber (ADF), neutral detergent fiber (NDF), hemicellulose, cellulose, and an extract substance without nitrogen. The results can be concluded that the Pandan Wangi rice is able to produce the highest fresh weight of forage feed if given by $10 \%$ OLF of a Unitas Super.
\end{abstract}

Keywords: Cisokan, forage animal feed, organic liquid fertilizer, Pandan Wangi, ratoon rice crop 


\section{PENDAHULUAN}

Tanaman padi merupakan penyedia makanan pokok utama bagi bangsa Indonesia. Hingga saat ini kecenderungan mengimpor beras bagi bangsa Indonesia juga masih tinggi. Data dari BPS (2016) menunjukkan bahwa Indonesia masih surplus beras, akan tetapi peningkatan produksi beras dari tahun ke tahun tidak signifikan. Peningkatan produksi gabah dalam jangka 10 tahun hanya mencapai 0,5 ton/ha, atau rerata hanya $41,66 \mathrm{~kg} / \mathrm{ha} /$ tahun. Nilai peningkatan ini relatif kecil, oleh sebab itu untuk meningkatkan produksi padi per tahun dapat dipercepat dengan budidaya ratoon. Jamilah et al. (2017) membuktikan padi ratoon yang dikembangkan dari hasil tanam padi musim tanam 1, dapat dipanen 1 bulan lebih cepat.

Ratoon merupakan upaya menumbuhkan tanaman baru yang berasal dari bagian vegetatif tanaman sebelumnya (Plucknett dan Evenson, 1970). Budidaya ratoon adalah upaya memelihara tunggul padi bekas panen pada musim tanam 1, dipangkas lagi setinggi sekitar $5 \mathrm{~cm}$ dari permukaan tanah, kemudian dibiarkan tumbuh selayaknya tanaman padi biasa. Jamilah et al. (2017), Harrell et al. (2009), Beuzelin et al. (2012) membuktikan bahwa beberapa keuntungan dari budidaya padi ratoon adalah, menghemat benih padi, beras yang dihasilkan sesuai rasanya dengan musim tanam 1, umur panen lebih singkat, tidak perlu olah tanah dan produksi meningkat. Budidaya padi ratoon telah mendapat apresiasi oleh petani di Indonesia.

Budidaya ratoon juga dilakukan dengan memangkas tanaman padi sebelum berbunga untuk diambil hijauan pakan ternak (HPT). Hijauan tersebut memiliki kandungan nutrisi yang baik dijadikan sebagai pakan ternak untuk pertumbuhan ternak dan produksi daging. Tindakan ini dilakukan untuk mengatasi keterbatasan lahan untuk budidaya rumput. Pemangkasan tanaman padi ratoon menjadi hal penting dalam pengadaan HPT.

Secara umum budidaya tanaman padi sawah, yang intensif menggunakan pupuk Urea, TSP atau SP36 dan $\mathrm{KCl}$ dengan dosis tinggi, sehingga dapat menyebabkan pencemaran lingkungan Salah satu alternatif untuk mengatasi hal ini adalah dengan pemberian pupuk orgaik cair (POC).

Fakultas Pertanian Universitas Tamansiswa Padang telah menghasilkan dua jenis POC yaitu Crocober Plus dan Unitas Super yang berasal dari komposisi bahan baku yang berbeda. Kedua jenis pupuk organik cair tersebut berbahan baku Chromolaena odorata dan sabut kelapa. Chromolaena odorata (C.odorata) merupakan tanaman semak yang dapat berkembang secara invasif dan sangat mengganggu petani karena mempersempit areal tanam. Tanaman C.odorata terbukti menghasilkan bahan alelopati yang dapat mengusir tanaman lain (Sahid dan Sugau, 2011, Prawiradiputra, 2007). Penggunaan POC untuk tanaman pangan di Sumatera Barat masih sangat terbatas. Beberapa bukti menunjukkan bahwa kemampuan tanaman menyerap unsur hara melalui daun jauh lebih cepat dibandingkan melalui akar (Oosterhuis, 2009). Aplikasi POC Crocober dan Unitas Super sudah dibuktikan keunggulannya pada tanaman padi ladang (Jamilah, 2017), padi sawah (Jamilah dan Helmawati, 2015), dan tanaman bawang (Jamilah dan Novita, 2016). Aplikasi POC sebagai pupuk daun selain dapat meningkatkan hasil tanaman padi sawah, juga dapat mengurangi penggunaan pupuk buatan hingga 25\% (Jamilah, et al. 2015). Peranan POC yang diproduksi oleh Fakultas Pertanian Universitas Tamansiswa 
Padang perlu dibuktikan keunggulannya dibandingkan dengan POC komersil yang dijual di pasar untuk meningkatkan produksi dan kualitas HPT yang berasal dari tanaman padi ratoon. Tujuan penelitian adalah untuk mengetahui jenis POC dan varietas padi yang tepat dalam menghasilkan produksi HPT tinggi dan berkualitas untuk meningkatkan ketahanan pangan di Indonesia.

\section{METODE}

Percobaan dilakukan di Nagari Ikur Lubuk Kecamatan Padang Panjang Timur, Kota Padang panjang, dengan ketinggian tempat mencapai $720 \mathrm{~m}$ dari permukaan laut (dpl). Percobaan dilakukan pada Bulan Maret 2017- Juli 2017 pada tanaman padi bekas panen Musim 1. Rancangan percobaan yang digunakan adalah split plot. Petak utama adalah varietas padi terdiri atas Cisokan dan Pandan Wangi. Anak petak terdiri atas tiga jenis POC yaitu; Crocober Plus, Unitas Super dan POC Komersil NASA. Setia perlakuan diulang sebanyak tiga kali, sehingga terdapat 18 plot percobaan, dengan ukuran plot $2 \times 2 \mathrm{~m}$. Jarak tanam yang digunakan $25 \times 25 \mathrm{~cm}$ dengan 1 anakan per titik tanam. Setelah tanaman padi dipanen pada musim tanam 1 , maka tunggul padi yang tersisa siap dijadikan tanaman padi ratoon. Tanaman padi ratoon dipangkas setinggi merata $5 \mathrm{~cm}$ dari permukaan tanah, 1 minggu setelah panen musim tanam 1. Tanaman padi ditumbuhkan normal dan pada saat 30 hari setelah pangkas ratoon dilakukan pemangkasan hijauan pakan ternak (HPT).

Pupuk buatan diberikan hanya $75 \%$ dari rekomendasi pemupukan khusus untuk padi sawah. Pemberian POC CP dan US diberikan hanya $1 / 2$ rekomendasi dari yang telah diberikan pada induknya, yaitu hanya
$10 \%$ setiap 2 minggu sekali hingga tanaman memasuki pengisian malai. Pupuk cair NASA diberikan sesuai rekomendasi yang tertulis dibotolnya, karena ini merupakan pupuk komersil. Pemangkasan HPT dilakukan saat 30 hari setelah pangkas ratoon, dan lebih cepat 10 hari perolehan HPT dibandingkan induknya pada MT 1.

Data yang diperoleh dianalisis dengan uji $\mathrm{F}$ taraf nyata 5\%. Jika perlakuan berpengaruh nyata dilanjutkan dengan uji BNT taraf nyata 5\%. Peubah yang diamati meliputi analisis van Soest seperti; proksimat, kecernaan dari protein kasar, lemak, serat kasar, bahan organik, bahan kering, ADF, NDF, hemiselulosa, selulosa, dan BETN.

Penetapan NDF dilakukan dengan menggunakan larutan neutral detergent sebanyak $6.81 \mathrm{~g}, \quad$ sodium borate decahydrate $\left(\mathrm{Na}_{2} \mathrm{~B}_{4} \mathrm{O}_{7}-10 \mathrm{H}_{2} \mathrm{O}\right)$ yaitu $18.61 \mathrm{~g}$ disodium ethylenediamin eter acetate (EDTA, $\mathrm{C}_{10} \mathrm{H}_{14} \mathrm{~N}_{2} \mathrm{Na}_{2} \mathrm{O}_{8}$ ); $30 \mathrm{~g}$ sodium lauryl sulfate neutral $\left(\mathrm{C}_{12} \mathrm{H}_{25} \mathrm{NaO}_{4} \mathrm{~S}\right) ; 10 \mathrm{ml}$ 2-ethoxyethanol (ethylene glycol monoethyl ether, cellosolve, $\left.\mathrm{C}_{4} \mathrm{H}_{10} \mathrm{O}_{2}\right) ; 4.56 \mathrm{~g}$ disodium phosphate anhydrous $\left(\mathrm{Na}_{2} \mathrm{HPO}_{4}\right), 1000 \mathrm{ml}$ air destilasi. Sodium borate dan disodium EDTA dituangkan ke dalam gelas beaker dan dilarutkan dengan air destilasi menggunakan panas, dan ditambahkan lauryl sulfate dan 2-ethoxyethanol. Disodium fosfat yang larut di dalam air distilasi dipisahkan menggunakan pemanas hingga larut sempurna. Kedua larutan tersebut dicampurkan dengan menghabiskan sisa air destilasi serta mengatur $\mathrm{pH}$ antara 6.9 dan 7.1.

Reagen untuk penetapan ADF (Suparjo, 2010), adalah larutan detergen asam yaitu dengan mencampurkan $20 \mathrm{~g}$ cetyltrimethyl ammonium bromide 
technical grade $\left(\mathrm{C}_{19} \mathrm{H}_{42} \mathrm{BrN}\right)$ dan 11 asam sulfat $1 \mathrm{~N}\left(\mathrm{H}_{2} \mathrm{SO}_{4}, 49.04 \mathrm{~g} / \mathrm{l}\right)$. Bahan ini kemudian dilarutkan menggunakan tensio aktif ke dalam asam sambil diaduk untuk meningkatkan penghancuran; n-octanol $\left(\mathrm{C}_{8} \mathrm{H}_{18} \mathrm{O}\right)$ octilic alcohol; aseton. Penetapan NDF (serat ditergen netral) dilakukan dengan menggiling sampel kering udara dengan ketentuan lolos ayak $1 \mathrm{~mm}$ diameter saringan. Kemudian dilakukan penimbangan sebanyak $1 \mathrm{~g}$ sampel halus ditambahkan $100 \mathrm{ml}$ (NDF) ke dalam gelas piala. Selanjutnya ditambahkan $0,5 \mathrm{~g} \mathrm{Na}-$ sulfit dan diberi beberapa tetes n-octanol dan dipanaskan hingga mendidih selama 60 menit; disaring dan dicuci 3 kali dengan air panas kemudian 2 kali dengan aseton dingin; pekerjaan selanjutnya adalah melakukan pengeringan selama 8 jam dan selanjutnya dimasukan ke dalam desikator sampai sejuk. Tahap berikutnya adalah menimbang bobotnya, dengan menghitung NDF dengan rumus: NDF \% = (Bobot gelas piala + bobot residu) - bobot gelas piala/bobot sampel x 100. Penetapan kelarutan (neutral detergent solubles) adalah NDS $\%=100$ - NDF $\%$. Pekerjaan terakhir adalah mengabukan di dalam muffle pada suhu $550^{\circ} \mathrm{C}$, selama 2 jam dan selanjutnya dimasukkan ke dalam desikator hingga sejuk. Bobot abu yang tak larut dihitung dalam neutral detergent: abu yang hilang/bobot sampel x 100 .

\section{HASIL DAN PEMBAHASAN}

Bobot segar, bobot kering oven dan kering udara HPT dipengaruhi oleh varietas, sedangkan kadar abu HPT dipengaruhi oleh jenis POC.

Tabel 1. Bobot segar, kering udara, kering oven dan kadar abu HPT yang berasal dari tanaman padi (Oryza sativa L.)

\begin{tabular}{|c|c|c|c|c|c|c|}
\hline $\begin{array}{lr}\text { Jenis POC dan } \\
\text { varietas padi }\end{array}$ & $\begin{array}{l}\text { Bobot } \\
\text { segar }\end{array}$ & $\begin{array}{l}\text { Bobot PK } \\
\text { Dalam } \\
\text { HPT }\end{array}$ & $\begin{array}{l}\text { Bobot } \\
\text { kering } \\
\text { oven }\end{array}$ & $\begin{array}{l}\text { Bahan } \\
\text { kering } \\
\text { udara }\end{array}$ & $\begin{array}{l}\text { Kadar PK } \\
\text { dalam Bahan } \\
\text { segar }\end{array}$ & Kadar abu \\
\hline & $\mathrm{mg} \mathrm{ha}^{-1}$ & $\mathrm{~kg} \mathrm{ha}^{-1}$ & $\mathrm{mg} \mathrm{ha}^{-1}$ & & $\%$ & \\
\hline \multicolumn{7}{|l|}{ Cisokan } \\
\hline $\mathrm{CP}$ & 7,71 & 294,52 & 1,53 & 1,91 & 3,82 & $8,42^{b}$ \\
\hline US & 7,42 & 306,45 & 1,55 & 1,86 & 4,13 & $7,50^{\mathrm{a}}$ \\
\hline NASA & 7,50 & 309,75 & 1,66 & 1,97 & 4,13 & $8,28^{b}$ \\
\hline Rerata & $7,54^{b}$ & 303,86 & $1,58^{b}$ & $1,92^{b}$ & 4,03 & 8,07 \\
\hline \multicolumn{7}{|l|}{ Pandan Wangi } \\
\hline $\mathrm{CP}$ & 10,92 & 377,83 & 2,19 & 2,66 & 3,46 & $8,11^{\mathrm{b}}$ \\
\hline US & 10,98 & 424,93 & 2,18 & 2,67 & 3,87 & $6,89^{a}$ \\
\hline NASA & 11,42 & 435,10 & 2,32 & 2,70 & 3,81 & $7,18^{b}$ \\
\hline Rerata & $11,10^{\mathrm{a}}$ & 411,81 & $2,23^{\mathrm{a}}$ & $2,68^{\mathrm{a}}$ & 3,71 & 7,39 \\
\hline
\end{tabular}

CP: Crocober Plus; US: Unitas Super; NASA : POC komersil; PK: Protein Kasar

${ }^{a, b}$ superskrip yang berbeda pada kolom yang sama menunjukkan perbedaan yang nyata $(\mathrm{P}<0,05)$ dan sangat nyata pada $(\mathrm{P}<0,01)$.

Berdasarkan Tabel 1, dapat dijelaskan bahwa secara umum padi ratoon
Pandan Wangi menghasilkan bobot segar HPT lebih tinggi 32,07\% dibandingkan 
padi Cisokan, dan bobot kering 29, 15\% lebih tinggi dibandingkan padi Cisokan.. Rerata produksi hijauan segar mencapai 7,54 $\mathrm{mg} \mathrm{ha}^{-1}$ untuk Cisokan dan 11,10 mg $\mathrm{ha}^{-1}$ untuk Pandan Wangi atau setara dengan $754 \mathrm{~g} \mathrm{~m}^{2}$ untuk Cisokan dan $1110 \mathrm{~g} \mathrm{~m}^{2}$ untuk Pandan Wangi. Produksi hijauan segar padi masih lebih rendah dibandingkan hijauan segar asal rumput gajah. Seseray, et al., (2013) melaporkan rumput gajah yang diberi pupuk buatan dan pupuk kandang yang cukup mampu menghasilkan sebanyak $2,2-2,87 \mathrm{~kg} \mathrm{~m}^{2}$ hijauan segar. Hal ini menunjukkan bahwa padi Pandan Wangi hanya mencapai $50 \%$ kemampuan produksi hijauannya. Rerata produksi bahan kering Cisokan mencapai $632 \mathrm{~g} \mathrm{~m}^{2}$, dan Pandan Wangi $964 \mathrm{~g} \mathrm{~m}^{2}$. Kadar abu terendah

Tabel 2. Kandungan Protein Kasar, Serat Kasar, Lemak dan BETN analisis proksimat hijauan

\begin{tabular}{|c|c|c|c|}
\hline \multirow[b]{2}{*}{ Varietas } & \multicolumn{3}{|c|}{ Pemberian Pupuk Organik Cair } \\
\hline & $\mathrm{CP}$ & US & NASA \\
\hline \multicolumn{4}{|c|}{ Kadar protein Kasar (\%) } \\
\hline Cisokan & $12,82^{\mathrm{cB}}$ & $13,75^{\mathrm{aB}}$ & $12,97 \mathrm{Bb}$ \\
\hline Pandan Wangi & $13,12^{\mathrm{cA}}$ & $14,29^{\text {aA }}$ & $14,00 \mathrm{Ba}$ \\
\hline \multicolumn{4}{|l|}{ Serat kasar (\%) } \\
\hline Cisokan & $29,03^{\text {aA }}$ & $28,02^{\mathrm{bA}}$ & $29,01^{\mathrm{Aa}}$ \\
\hline Pandan Wangi & $28,77^{\mathrm{aB}}$ & $26,18^{\mathrm{cB}}$ & $28,06^{\mathrm{Bb}}$ \\
\hline \multicolumn{4}{|l|}{ Lemak (\%) } \\
\hline Cisokan & $1,92^{\mathrm{bB}}$ & $2,27^{\mathrm{aB}}$ & $2,00^{\mathrm{Bb}}$ \\
\hline Pandan Wangi & $2,10^{\mathrm{cA}}$ & $2,80^{\text {aA }}$ & $2,49 \mathrm{bA}$ \\
\hline \multicolumn{4}{|l|}{ BETN (\%) } \\
\hline Cisokan & $47,82^{\mathrm{bA}}$ & $48,47^{\mathrm{aB}}$ & $47,76^{\mathrm{bB}}$ \\
\hline Pandan Wangi & $47,91^{\mathrm{cA}}$ & $49,85^{\text {aA }}$ & $48,28^{b A}$ \\
\hline \multicolumn{4}{|c|}{ Bahan Organik (\%) } \\
\hline Cisokan & 91,59 & 92,50 & $91,72^{\mathrm{B}}$ \\
\hline Pandan Wangi & 91,90 & 93,11 & $92,82^{\mathrm{A}}$ \\
\hline rerata & $91,75^{\mathrm{c}}$ & $92,81^{\mathrm{a}}$ & $92,27^{\mathrm{b}}$ \\
\hline
\end{tabular}

dijumpai pada padi ratoon Pandan Wangi yang diberikan POC Unitas Super. Semakin rendah kadar abu menunjukkan bahwa hijauan pakan ternak akan menghasilkan bahan yang mengandung gizi yang penting untuk ternak ruminansia. Sebelumnya (Prawiradiputra, et al., 2012) menjelaskan bahwa produksi berat segar rumput yang mencapai 100 sampai 150 ton/ha/tahun atau sekitar $12,5-18,75$ ton satu kali pemotongan, mencukupi kebutuhan untuk 9 - 13 ekor sapi dengan berat badan $300 \mathrm{~kg}$. Jika dibandingkan dengan hasil padi Pandan Wangi, maka memberikan ketersediaan HPT untuk lebih kurang 8 ekor sapi.

\section{Pakan ternak (HPT)}


Hasil analisis proksimat, kandungan protein, serat kasar HPT tanaman padi ratoon yang diberi berbagai jenis pupuk organik cair (POC), setiap 2 minggu sekali hingga tanaman memasuki primordia bunga disajikan pada Tabel 2. Ada pengaruh interaksi antara POC Unitas Super (POC US) dan varietas padi. Pemberian POC US menghasilkan kandungan protein kasar, lemak dan BETN pada HPT varietas Pandan Wangi tertinggi dibandingkan perlakuan lain. Kandungan serat kasar tertinggi dijumpai pada HPT varietas Cisokan yang diberi POC $\mathrm{CP}$ dan tidak berbeda nyata dengan POC NASA, juga pada varietas yang sama.

Kandungan PK Pandan Wangi jika diberi POC US berkisar 14\%, yang tertinggi. Hal ini menunjukkan bahwa POC US jauh lebih berkualitas dibandingkan POC CP maupun NASA terhadap kualitas hijauan padi ratoon. Jika ditinjau pada kandungan analisis kedua jenis POC tersebut, maka POC US memiliki kandungan $\mathrm{N}>$ dibandingkan dengan $\mathrm{POC}$ CP (Jamilah et al., 2017), demikian juga beberapa unsur mikro lainnya mengalami hal yang serupa. Oleh karena itu diduga karena nutrisinya lebih tinggi maka HPT yang dihasilkannya juga lebih baik.

Selanjutnya jika membandingkan kualitas rumput gajah (Pennisetum purpureum) dari berbagai daerah dan negara memiliki PK rerata $13,72 \%$ dan SK berkisar 22- 33,66\% (Dwinarto et al., 2013); (Anonim, 2013). HPT asal padi Pandan Wangi ratoon mengandung SK sebesar 26-28\%, sehingga lebih baik kualitasnya dibandingkan rumput gajah dan semua jenis rumput yang biasa dijadikan sebagai hijuan pakan ternak, karena secara umum SK rumput lebih tinggi dibandingkan dengan SK padi. Nilai kecernaan BETN sejalan dengan kecernaan serat kasarnya. (Budiman et al., 2006) menyatakan bahwa komponen BETN terbesar adalah karbohidrat nonstruktural, seperti pati, monosakarida atau gula. Komponen ini banyak terdapat pada bijian serealia. Hasil penelitian ini menunjukkan peningkatan angka BETN diikuti dengan kenaikan kandungan PK. Peningkatan protein mengindikasikan adanya pengaruh terhadap penyerapan atau pemanfaatan zatzat makanan, sehingga kecernaan BETN meningkat.

Dari serat kasar tersebut, terkandung ADF, NDF hemisellulosa dan selulosa. Menurut (Beauchemin, 1996) kandungan ADF dapat digunakan untuk memprediksi kandungan energi pada HPT. Kandungan serat pada hijauan secara rutin ditetapkan sebagai serat ditergen asam (ADF). Pengukuran ADF untuk menetapkan suatu bagian dari dinding sel yaitu lignin dan sellulosa. Penetapan serat ditergen netral (NDF) digunakan untuk mengukur bahan dinding sel tanaman total, biasanya mengandung kebanyakan hemiselulosa, selulosa dan lignin. Hemiselulosa dan selulosa dicerna secara lambat oleh mikroba rumen, sementara ligin tidak bisa dicerna. Lignin sebagai pengikat lintas antara sel satu dengan lainnya. 
Tabel 3. Kandungan NDF, ADF, hemmiselulosa dan selulosa HPT pada berbagai jenis POC dan varietas padi

\begin{tabular}{|c|c|c|c|c|}
\hline \multirow[b]{2}{*}{ Varietas } & \multicolumn{4}{|c|}{ Pemberian Pupuk Organik Cair } \\
\hline & $\mathrm{CP}$ & US & NASA & Rerata \\
\hline \multicolumn{5}{|l|}{ NDF $(\%)$} \\
\hline Cisokan & 52,92 & 51,65 & 52,01 & $52,29^{\mathrm{B}}$ \\
\hline Pandan Wangi & 52,90 & 50,99 & 51,57 & $51,95^{\mathrm{A}}$ \\
\hline rerata & $52,91^{\mathrm{c}}$ & $51,32^{\mathrm{a}}$ & $51,79^{\mathrm{b}}$ & \\
\hline \multicolumn{5}{|l|}{$\operatorname{ADF}(\%)$} \\
\hline Cisokan & 40,11 & 39,09 & 39,83 & $39,68^{\mathrm{B}}$ \\
\hline Pandan Wangi & 39,75 & 38,75 & 39,06 & $39,10^{\mathrm{A}}$ \\
\hline rerata & $39,93^{\mathrm{c}}$ & $38,92^{\mathrm{a}}$ & $39,45^{\mathrm{b}}$ & \\
\hline \multicolumn{5}{|c|}{ Hemiselulosa (\%) } \\
\hline Cisokan & 12,96 & 12,61 & 12,31 & 12,63 \\
\hline Pandan Wangi & 13,16 & 12,24 & 12,51 & 12,64 \\
\hline rerata & $13,06^{\mathrm{a}}$ & $12,43^{b}$ & $12,41^{\mathrm{b}}$ & \\
\hline \multicolumn{5}{|l|}{ Selulosa (\%) } \\
\hline Cisokan & $23,90^{\mathrm{aA}}$ & $22,54^{\mathrm{bA}}$ & 23,68 aA & \\
\hline Pandan Wangi & $23,68^{\mathrm{aB}}$ & $21,60^{\mathrm{cB}}$ & $22,89^{\mathrm{bB}}$ & \\
\hline
\end{tabular}

rerata

${ }^{\mathrm{a}, \mathrm{b}}$ superskrip yang berbeda pada baris yang sama menunjukkan perbedaan yang nyata $(\mathrm{P}<0,05)$ dan sangat nyata pada $(\mathrm{P}<0,01)$.

A,B superskrip yang berbeda pada kolom yang sama menunjukkan perbedaan yang nyata $(\mathrm{P}<0,05)$ dan sangat nyata pada $(\mathrm{P}<0,01)$.

Kualitas HPT dari padi ratoon ditentukan oleh metoda Van Soest untuk menentukan banyaknya bahan hijauan yang mudah dicerna oleh ruminansia. Seperti yang dijelaskan oleh (Budiman et al., 2006) bahwa analisis serat Van Soest, konsepnya adalah membedakan bahan penyusun sel tanaman yang sulit dan mudah terurai. Bahan yang sulit terurai antara lain; hemiselulosa, selulosa dan lignin, dan bahan yang mudah terurai; antara lain pati dan gula. Pemisahan tersebut menggunakan dua ditergen yaitu; ditergen netral (Na-lauryl sulfate, EDTA, $\mathrm{pH}=7.0$ ) dan ditergen asam (acetyl trimethyl ammonium bromide dalam $1 \mathrm{~N} \mathrm{H}_{2} \mathrm{SO}_{4}$ ). Hemiselulosa, selulosa dan lignin adalah bahan yang sulit hancur, sementara hemiselulosa dan selulosa yang dapat hancur di ruminansia, NDF $=$ hemiselulosa + seluulosa + lignin $\mathrm{ADF}=$ selulosa + lignin. Serat ditergen netral adalah indikator terbaik dari bulk dan sumber pakan yang masuk. Serat ditergen asam adalah indikator terbaik dari yang bahan yang dapat dihancurkan dan pengambilan energi.

Kadar bahan organik cukup tinggi di dalam bahan hijauan pakan ternak, mencapai 91-92,81\%. Kadar bahan organik tertinggi diperoleh pada tanaman padi Pandan Wangi ratoon yang diberi POC Unitas Super. Kadar bahan organik ditetapkan berdasarkan bahan kering yang dihasilkan oleh hijauan segar yang dikurangi kandungan abu atau mineralnya. Semakin tinggi kadar bahan organik juga bisa mengindikasikan tingginya kandungan protein dan serat kasar. Jika bahan kering 
mengandung kadar protein tinggi, maka kandungan serat kasar menurun.

Demikian juga sebaliknya beberapa peubah telah membuktikan bahwa POC US lebih unggul dibandingkan dengan POC $\mathrm{CP}$, disebabkan POC US mengandung unsur hara yang lebih tinggi dibandingkan
CP. Walaupun kedua jenis POC tersebut memiliki kandungan bahan baku yang sama, namun perbedaannya pada POC US ada tambahan urine dan batang pisang, sehingga meningkatkan kualitas nutrisi POC menjadi lebih baik dibandingkan CP.

Tabel 4. Kecernaan HPT padi ratoon yang dipangkas 30 hari setelah ratoon yang diberi berbagai jenis POC

\begin{tabular}{|c|c|c|c|c|}
\hline \multirow[b]{2}{*}{ Varietas } & \multicolumn{4}{|c|}{$\begin{array}{l}\text { Pemberian } 10 \% \text { berbagai jenis Pupuk Organik Cair setiap } 2 \text { minggu } \\
\text { sekali }\end{array}$} \\
\hline & $\mathrm{CP}$ & US & NASA & Rerata \\
\hline \multicolumn{5}{|c|}{ Kecernaan PK (\%) } \\
\hline Cisokan & $69,91^{\mathrm{bB}}$ & $71,57^{\mathrm{aB}}$ & $70,14^{\mathrm{bB}}$ & \\
\hline Pandan Wangi & $70,59^{\mathrm{cA}}$ & $72,10^{\mathrm{aA}}$ & $71,80^{\mathrm{bA}}$ & \\
\hline \multicolumn{5}{|c|}{ Kecernaan SK (\%) } \\
\hline Cisokan & 68,07 & 69,24 & 68,79 & $68,70^{\mathrm{B}}$ \\
\hline Pandan Wangi & 69,31 & 70,21 & 69,31 & $69,61^{\mathrm{A}}$ \\
\hline Rerata & $68,69^{c}$ & $69,73^{\mathrm{a}}$ & $69,05^{\mathrm{b}}$ & \\
\hline \multicolumn{5}{|c|}{ Kecernaan NDF (\%) } \\
\hline Cisokan & $72,22^{b A}$ & $73,61^{\mathrm{aB}}$ & $71,01^{\mathrm{cB}}$ & \\
\hline Pandan Wangi & $72,37^{\mathrm{cA}}$ & $74,75^{\mathrm{aA}}$ & $73,06^{\mathrm{bA}}$ & \\
\hline \multicolumn{5}{|c|}{ Kecernaan ADF (\%) } \\
\hline Cisokan & $70,95^{\mathrm{bB}}$ & $72,79^{\mathrm{aB}}$ & $70,65^{\mathrm{bB}}$ & \\
\hline Pandan Wangi & $71,68^{b A}$ & $73,80^{\text {aA }}$ & $73,26^{\mathrm{aA}}$ & \\
\hline \multicolumn{5}{|c|}{ Kecernaan BO (\%) } \\
\hline Cisokan & 64,88 & 66,93 & 65,87 & $65,89^{\mathrm{B}}$ \\
\hline Pandan Wangi & 66,78 & 67,90 & 66,82 & $67,17^{\mathrm{A}}$ \\
\hline Rerata & $65,83^{\mathrm{c}}$ & $67,42^{\mathrm{a}}$ & $66,35^{b}$ & \\
\hline
\end{tabular}

Pengaruh POC dan varietas pas padi yang diratoonkan terhadap kandungan NDF, ADF, hemiselulosa dan selulosa HPT disajikan pada Tabel 3 dan kecernaannya disajikan pada Tabel 4. Kandungan NDF dan ADF lebih rendah pada ratoon Pandan Wangi dibandingkan Cisokan. Demikian juga pemberian POC Unitas Super menghasilkan jenis HPT yang lebih mudah dicerna oleh ruminansia. Hal ini kandungan ADF dan NDF lebih rendah dibandingkan Crocober Plus dan pupuk organik komersial NASA. Kandungan ADF dan NDF yang tinggi menunjukkan bahwa HPT lebih sulit dicerna. Kandungan nitrogen yang lebih tinggi pada POC US dibandingkan POC CP 
mampu menurunkan kadar ADF dan NDF pada ratoon padi. Hal ini juga dijelaskan oleh (Oosterhuis, 2009) bahwa unsur $\mathrm{N}$ diserap tanaman dan kemudian berfungsi dalam pembentukan chlorofil dan protein. Kandungan protein meningkat maka akan menurunkan kandungan serat kasar. Demikian pula halnya terhadap kecernaan bahan hijauan tersebut di rumen sapi. Protein kasar mampu diserap hingga mencapai $72 \%$ pada ratoon Pandan Wangi yang diberi POC US, sedangkan serat kasar yang mampu dicerna mencapai 70\%. Dari kandungan NDF yang mencapai 51\%, maka yang mampu dicerna oleh rumen sapi mencapai 74,75\%, sedangkan ADF yang hanya $38,92 \%$ kandungannya, dicerna mencapai 73,8\%.

Kandungan serat kasar masih memiliki komponen yang sangat menentukan apakah bahan tersebut mudah dicerna atau tidak di lambung sapi. Komposisi ADF, NDF, sangat menentukan hal tersebut. Makin tinggi angka-angka pada Tabel 2, menunjukkan bahwa bahan tersebut sulit dicerna kecuali pada kadar hemiselulosa.

Protein kasar pada HPT padi Pandan Wangi ratoon yang diberi POC US ada sebanyak 14,29\%. Dari kandungan tersebut hanya $2 / 3$ bagian mampu diserap oleh perut sapi, sisanya terbuang sebagai feses. Secara umum kecernaan semua unsur yang berasal dari HPT mencapai 69-74\%. Hal ini menunjukkan bahwa HPT tanaman padi ratoon Pandan Wangi merupakan bahan pakan yang berkualitas dalam upaya penggemukan maupun untuk pertumbuhan hidup sapi atau ternak ruminansia. Hynes et al. (2016) telah menjelaskan bahwa kandungan gizi dan kemudahan kecernaan dari sumber makanan atau hijauan menentukan untuk meningkatkan pertumbuhan ternak ruminansia. Selanjutnya (Dehghani et al., 2012) membuktikan bahwa kemudahan cerna dari hijauan tersebut tidak terlepas dari peranan enzim, diantaranya enzim fibrolitik, selulase, hemiselulase dan pektinase. (Beauchemin, 1996) (Macome et al., 2017); (Budiman et al., 2006) telah membuktikan juga bahwa meningkatnya kandungan NDF dari 32 ke $40 \%$ (12 ke 32\% NDF pada hijauan), menurunkan produksi susu akan tetapi meningkatkan kandungan lemaknya.

\section{KESIMPULAN DAN IMPLIKASI}

Berdasarkan hasil penelitian dapat disimpulkan bahwa tanaman padi Pandan Wangi ratoon yang diberi pupuk organik cair Unitas Super memberikan hijauan pakan ternak tertinggi dan lebih berkualitas dibandingkan padi Cisokan dan jenis POC lainnya.

\section{UCAPAN TERIMA KASIH}

Terima kasih disampaikan kepada Kemenristek Dikti yang sudah mendanai kegiatan riset ini melalui skim penelitian Strategis Nasional lanjutan tahun ke 3, melalui kontrak NO. 005/KONTRAKPENELITIAN/K10/KM/2017.

\section{DAFTAR PUSTAKA}

Anonim. 2013. Pengetahuan Bahan Makanan Ternak. Bogor: CV Nutrisi Sejahtera.

BPS [Badan Pusat Statistik]. 2016. Output tabel dinamis of Badan Pusat Statistik Indonesia. http://www.bps.go.id/mod/exportD ata/exportPDF.php, diakses tanggal 7 April 2017. 
Beauchemin K A. 1996. Using ADF and $\mathrm{NDF}$ in dairy cattle diet formulation - a western Canadian perspective. Anim. Feed Sci. Tech. 58: 101-111.

Beuzelin, J., M. A. Mészáros, M. O. Way, and T. E. Reagan. 2012. Rice harvest cutting height and ratoon crop effects on late season and overwintering stem borer (Lepidoptera crambidae) infestations. Crop Protection 34: 4755.

Budiman A, Dhalika T, Ayuningsih B. 2006. Uji kecernaan serat kasar dan bahan ekstrak tanpa nitrogen (BETN) dalan ransum lengkap berbasis hijauan daun pucuk tebu (Saccharum officinarum). Jurnal Ilmu Ternak 6: 132-135.

Dehghani MR, Weisbjerg MR, Hvelplund T, Kristensen NB. 2012. Effect of enzyme addition to forage at ensiling on silage chemical composition and NDF degradation characteristics. Livestock Science 150: 51-58.

Dwinarto B, Bogassara E, Wida A. 2013. Hasil Uji Bahan Pakan dan Hijauan Pakan Ternak. Direktur Jenderal Peternakan, Departemen Pertanian, Jakarta. diakses tanggal 28 Juni 2017.

Harrell DL, Bond JA, BlancheS. 2009. Evaluation of main-crop stubble height on ratoon rice growth and development. Field Crops Research 114: 396-403.

Hynes DN, Stergiadis S, Gordon A, Yan T. 2016. Effects of concentrate crude protein content on nutrient digestibility, energy utilization, and methane emissions in lactating dairy cows fed fresh-cut perennial grass. J. Dairy Sci. 99: 8858-8866.

Jamilah. 2016. Pengaruh pupuk organik cair asal C.odorata terhadap serapan hara kalium dan hasil padi ladang. Jurnal Bibiet 1: 17-26.
Jamilah, Ediwirman, and M. Ernita. 2015. The effect of fermented liquid organic fertilizer and potassium for nutrient uptake and yield of rice at tropical upland. J. Environ. Res. Develop. 9: 16.

Jamilah, Fadhila R, Mulyani S. 2017. Farm analysis of rice crop trimmed periodically in the tropical wet. In International Conference on Social, Humanities and Government Science, Universitas Tamansiswa Palembang, pp. 631.

Jamilah, Helmawati. 2015. Kajian analisis usaha tani integrasi padi sawah dan pakan ternak ruminansia menunjang kedaulatan pangan dan daging dalam menghadapi masyarakat ekonomi Asean 2015. Asmai Ishak, Anas Hidayat, Agus Hardjito, Zaenal Arifin, Sutrisno (Ed.), Seminar Nasional Kesiapan Indonesia dalam Pasar Bebas ASEAN melalui Penguatan Implementasi Corporate Governance yang Sehat " Bung Hatta, pp. 254266.

Jamilah, Novita E. 2016. Pengaruh pupuk organik cair crocober terhadap tanaman bawang merah (Allium ascalonicum L.). Jurnal Ipteks Terapan 8: 67-73.

Macome, F. M., W. F. Pellikaan, J. T. Schonewille, A. Bannink, H. van Laar, W. H. Hendriks, and J. W. Cone. 2017. In vitro rumen gas and methane production of grass silages differing in plant maturity and nitrogen fertilisation, compared to in vivo enteric methane production. Anim. Feed Sci. Technol. 1: 1-20.

Oosterhuis, D. 2009. Foliar fertilization: mechanisms and magnitude of nutrient uptake. Proceedings of the Fluid Forum. pp 15-17.

Plucknett D, Evenson JP. 1970. Ratoon Cropping. Advances in Agronomi 22: 285-330. 
Prawiradiputra B R, Sutedi E, Sajimin, Fanindi A. 2012. Hijauan pakan ternak untuk lahan sub-optimal. Badan Penelitian dan Pengembangan Pertanian Kementerian Pertanian.

Sahid I B, Sugau JB. 2011. Allelopathic Effect of Lantana (Lantana camara) and Siam Weed (Chromolaena odorata) on Selected Crops. Weed Science 41: 303-308.

Seseray DY, Santoso B, Lekitoo N. 2013. Produksi rumput gajah (Pennisetum purpureum) yang diberi pupuk $\mathrm{N}, \mathrm{P}$ dan $\mathrm{K}$ dengan dosis 0, 50 dan $100 \%$ pada devoliasi hari ke-45. Sains Peternakan 11: 49-55.

Suparjo. 2010. Analisis Proksimat (Proximate Analysis). Suparjo (Ed.). Universitas Jambi, https://jajo66.files.wordpress.com/2 010/10/analisis-kimiawi 2010.pdf. diakses tanggal 9 Juni 2017. 